MAŁGORZATA TRENKNER

\title{
Implementation of lean leadership
}

Małgorzata Trenkner, Ph.D. University of Economics in Wrocław
"Before we built cars, we built people"

Toyota culture

\section{Introduction}

The Toyota case proves that lean leadership is of critical importance for the successful implementation and permanent functioning of LPS (Lean Production System). What is the formula for a Toyota style success? If there is any at all, according to J. Liker and G. Convis (2012, p. 49), this is a thorough, time-consuming and expensive investment in the development of each member of an organization and a deep belief that employees are the most valuable resource of the organization. The role of a lean leader is to be open to personal development necessary to take care of one's leadership skills, to inspire and support one's subordinates so that they develop, improve and overcome obstacles and formulate challenges and objectives so that teams at each level of the organization have their contribution to the continuous improvement and the achievement of long-term objectives.

Referring to the major model of the Toyota Way (4P) (Liker 2005, p. 34), consisting of four levels necessary for the implementation of a permanent Lean Production System, namely: philosophy (long-term thinking), process (elimination of waste), people and partner (respect, challenges and development), 
problem solving (CIP - continuous improvement process and learning), it should be stated that lean leadership is focused on all 4Ps and provides methods enabling the permanent implementation and continuous improvement of the Lean Production System. It puts great emphasis on the cooperation between employees and leaders in collective efforts to reach excellence.

Practice shows that numerous implementations of the Lean Management concept do not meet the hope vested in them from the long-term perspective. Companies achieve significant successes especially in the first years after the implementation of the lean concept, focusing mostly on the elimination of waste by introducing various lean tools, namely 5S, SMED, VSM, TPM etc. However, sooner or later the lean program ceases to meet the expectations and stagnation takes place. The elimination of waste is an important element of the lean concept but it does not create a genuine lean thinking and, in consequence, the continuous improvement process (CIP). Leadership should be an important link between the reduction of waste and continuous improvement (Dombrowski, Mielke 2014, p. 565).

The significance of lean leadership and how to implement it in practice are described by numerous authors (Ciarniene, Vienazindiene 2015; Dombrowski, Mielke 2013; Dombrowski, Mielke 2014; Emiliani 1998; Friedman 2014; Holtskog et al. 2016; Lodgaard et al. 2016; Nogalski 2010; Orr 2005; Walentynowicz 2013). Companies expect practical instructions with regard to the implementation of lean leadership, indicators to measure the effectiveness of leadership etc. Therefore, the question which principles (recommendations) should comprise lean leadership and what their implementation looks like in the practice of companies arises again and again.

The purpose of the article is to present analyze and assess the implementation of lean leadership in the practice of companies. The study uses the following research methods: studies of literature on the subject, results of research by other authors as well as the results of the author's own case study conducted by means of categorized interviews.

\section{Leadership model at Toyota}

The forerunner of lean solution is Toyota, which created and developed the model for lean leadership; it can be the reference model for companies wishing to follow the lean way. The culture of leadership at Toyota was shaped by personalities, values and experience of the company's founders. It is where the features distinguishing the Toyota leadership style come from, namely the 
readiness to face seemingly unattainable objectives and the requirement for leaders to thoroughly become familiar with the company's operation, being involved in it personally (Liker 2005, p. 273).

Leadership at Toyota is a personal task, but it also has an institutional nature and extends from production halls to the CEO's chair. Institutional leadership may exist only with the support from strong individual leaders, sharing the same philosophy and values at each level of the hierarchy. Five values defining the Toyota Way (values of True North) include: spirit of the challenge, kaizen, genchi genbutsu, teamwork and respect (Liker, Convis 2012, p. 70). These values are the foundation on which leadership is built but following these values itself will not make a leader out of anyone. Toyota uses a system of regular identification and systematic development for leaders, although this process has never been formalized (as opposed to key values) (Liker, Convis 2012, pp. 70-74).

Toyota developed a model for the development of leadership containing a comprehensive approach to lean leadership. It consists of four stages:

1. Self-improvement (learning Toyota's values by repeated learning cycles): Natural leaders notice the possibilities to improve themselves and others, and instinctively adapt to Toyota's values. They go to gemba (the place of work) so as to thoroughly understand the actual situation and undertake greater and greater challenges under the supervision of a mentor.

2. Coaching and stimulating the development of others: Leaders recognize the strengths and weaknesses of their subordinates learn how to create conditions favorable for the development of employees and how to achieve the best possible effects with the smallest intervention in the learning process. They focus on the proper stimulation of the employees' development, being aware of the fact that the effects will come on their own. They assume the responsibility for supporting people in progress on the road of development according to the learning cycle.

3. Supporting the daily kaizen process: Leaders promote the idea of leadership development several levels below by standards, objectives and visual management. Leaders should be present at gemba where they check the indicators of visual management and define the distance between the execution and True North. Leaders instruct employees so that they assume responsibility for minimizing this distance.

4. Creating the vision and coordinating objectives (horizontal and vertical coordination towards True North): Leaders participate in a collective process leading the agreement and adaptation of objectives and methods of achieving them (Hoshin Kanri). They initiate and maintain the continuous improvement 
process by means of visual management depicting objectives; they focus on solving problems and the development of employees (Liker, Convis 2012, pp. 65-67).

This model is applied both in the case of individual development and the development of the company. The first two stages focus more on individual development at the level of the individual and at the level of the group. Toyota's leaders are to perform both of these steps at the same time (work on their own development and support the learning and develop the potential of their subordinates at the same time), although a certain degree of personal development is required before beginning the stimulation of the employees' development. The cyclical nature of the process means that the leader who leads a team to achieve coordinated objectives on a certain section of works at an earlier stage of career, focuses on personal development again later as they hold a higher position in the organization, requiring other skills. Each leader goes through all stages many times during their career. Only when the leaders at each level of the organization go through all steps several times, we may say that the organization reached a certain level of maturity in leadership (Liker, Convis 2012, p. 75).

The process of identifying leadership potential at Toyota starts from training the employee at the lowest level of the hierarchy by sensei (the master, the teacher). The role of sensei is to provide challenges, organized (rather than accidental) chances to show one's skills and support so that the apprentice learns through practice. However, it is the apprentice that decides whether they want to face the challenges. In many cases sense $i$ is a direct superior or a superior two levels higher (Liker, Convis 2012, pp. 87-88).

J. Liker, M. Hoseus introduced the concept "servant leadership" in the book Toyota Culture (Liker, Franz 2013, p. 57). Managers become responsible for how to perform work adding value and the development of employees. They may be compared to master craftsmen who educate and stimulate the development of their apprentices. A leader professing the principle of "servant leadership" needs to earn deep respect; he should also be humble (Miller et al. 2014, p. 111).

Requirements formulated for Toyota heads are as follows. They should:

- actively observe the organization's work without prejudice,

- actively listen so as to understand what people actually have to say,

- use the system's thinking approach,

- know and understand the actual strengths and weaknesses of each person,

- clearly define problems and identify their causes,

- creatively prevent the sources of problems, 
- plan and bring plans into action with a clearly defined scope of responsibility, - find the time and enthusiasm for a deep reflection so as to identify further opportunities for improvement,

- motivate and inspire people throughout the organization to act for a common objective,

- be able to teach other employees all the skills above (Liker, Convis 2012, p. 90). The leadership development model at Toyota is a mechanism Toyota has been improving for years. It is aimed at instilling the company's DNA in each leader. It starts with a thorough selection of new employees who are then shaped inside the organization; then, on the basis of leadership skills presented by them and the ability to learn from one's own experience, greater and greater challenges are formulated for them. Only those employees who show a high degree of competences have a chance to be promoted to the leader position (Liker, Convis 2012, p. 286).

In turn, charisma is not a feature Toyota searches for in its leaders. People from the outside perceive numerous Toyota leaders as quite ordinary. Toyota prefers modest, responsible people willing to work in a team and open to learning. Competent leaders who demonstrate their skills at work all the time are highly appreciated.

To sum up, we may say that a leader in lean leadership serves a special role - they are to be a role model and an example to be followed by others. In addition, they are to provide support and assist employees, mostly in the form of coaching. Lean leaders should have: basic technical skills allowing them to understand the processes and tools of continuous improvement, a natural curiosity, a strong thirst for learning and personal development, basic skills in leading presentations, the ability to communicate with different people at each organizational level, the ability to listen, respect from their co-workers, passion for improving the organization (Liker, Franz 2013, p. 439).

The leadership development model proposed by Toyota may be used as a unique diagnostic test in each company using the lean approach for measuring the distance between the current and the target condition of leadership, by formulating the following questions (Liker, Convis 2012, pp. 299-301):

- Does the organization have a collective system of values shared by all?

- Do we have leaders who are willing to take challenges and develop?

- Do the leaders at each level of the organization assume the role of teachers working on the development of others?

- Do the leaders at each level of the organization benefit from the method of disciplined problem solving? 
- Has the company created an environment in which objectives bringing improvement are concentrated at each level, and do people throughout the organization share good ideas for achieving them?

- Do we use challenges formulated by the environment to strengthen leadership and the organization?

\section{Lean leadership - results of secondary research}

The principles of lean leadership are more and more commonly known and applied. What managers' lack is the adaptation of these recommendations to the specific nature of their company. U. Dombrowski, U. Mielke (2014, p. 565) present the practical principles of lean leadership based on five fundamental lean areas: the culture of continuous improvement (the pursuit of perfection, the use of errors as an occasion to improve), self-improvement (lean leaders are to be models to follow), qualifications (long-term development of employees, continuous learning), gemba (shop floor management, decisions based on personal experience), Hoshin Kanri (focus on the customer, consistency of objectives at all levels of the organization). These principles include:

1. The area of the culture of continuous improvement:

- consistent, continuous and internally consistent leadership (resulting from long-term personal development of leaders),

- lean leaders should support the problem solving process rather than help employees out in solving problems,

- Giving the employees the right to make mistakes.

2. The area of self-development:

- the leader's self-awareness (regarding the identification of their development needs) is the first step towards self-improvement,

- the leader's promotion should involve the internalization of the previous knowledge and skills (leaders should remember where they came from),

- lean leadership requires various skills and behaviors (the identification of the customers' needs and translating them into the objectives of particular processes and employees).

3. The area of qualifications:

- lean leaders should lead a team towards independence (they should educate their successors),

- lean leaders should focus on the individual development of each employee,

- learning (through problem solving) should take place in short cycles (feedback is to support the employees' motivation and cooperation between them). 


\section{The area of gemba:}

- lean leaders should make decisions based on personally confirmed facts in gemba (the genchi genbutsu principle),

- lean leaders should use visit in gemba as the possibility to learn,

- leadership in gemba (at the production level) requires small teams (approx. 5 people). Only then a leader will be able to devote enough attention to every employee.

5. The area of Hoshin Kanri

- leaders should never abandon long-term objectives for short-term objectives,

- leaders should ensure that the employees' development is found within the company's objectives,

- it is necessary to define precise intermediate objectives in the pursuit of perfection.

These principles should support lean leaders in their daily efforts for continuous improvement. The authors encourage verifying these principles in practice; they also undertook this task themselves. In 2012 U. Dombrowski and $\mathrm{U}$. Mielke conducted a research on the group of 91 companies representing various industries. According to the research, the vast majority of the examined companies apply the principles of lean leadership from the area of the culture of continuous improvement and the area of qualifications. Half of the respondents admitted to applying the principles from the area of gemba in practice, approx. $40 \%$ of the respondents apply the principles from the area of self-development, while $30 \%$ of the respondents - from the area of Hoshin Kanri. To sum up the research results, we may say that companies notice the significance of lean leadership but they have problem with its application. This applies especially to the principles from the following areas: gemba, self-improvement and Hoshin Kanri. This requires greater cooperation between the employees and the leaders (Dombrowski, Mielke 2013, pp. 572-573).

Nine behaviors from the area of lean leadership were also presented by M. Denison, an expert of the Toyota Production System (quoted after Orr 2005, p. 347). These include:

- teaching and commitment of working groups,

- respect for people,

- focus on the process,

- support and appreciation of accomplishments,

- giving examples,

- implementation of policies and determination of objectives,

- pursuit of standardization, 
- long-term vision and principles,

- supporting the change process.

According to M. Denison, the listed attitudes and behaviors are universal and will prove correct in companies and organizations of various types.

The significance of lean leadership problems is also confirmed by the results of research conducted by P. Walentynowicz (2013, pp. 246-254). The purpose of the research was to identify the conditions for an effective implementation of Lean Management in production companies in Poland. Eight large and medium companies were examined. The conducted research implies that the main factor fostering the effective implementation of Lean Management was the leadership style of company management. In turn, the barriers included: poor knowledge of the top management on lean, poor training system in this area and the lack of commitment from the line management towards lean actions, and poor commitment from the top management towards the implementation of this management concept.

Subsequent results of research conducted by $\mathrm{R}$. Ciarniene and $\mathrm{M}$. Vienazindiene (2015, pp. 229-231) on a group of 72 Lithuanian companies from various industries show that the major barriers for the implementation of Lean Management include: the lack of sufficient knowledge on Lean Management and motivation for actions from the lean area, in addition - the lack of support from the top management and reluctance towards changes. All listed barriers are related to the human factor and the role of managers in the implementation of the Lean concept.

The confirmation of the presence of "soft" barriers for the implementation of Lean is the result of a the research conducted with the use of a case study by E. Lodgaard et al. (2016, p. 1122) in a large Norwegian production company. The purpose of the research was to recognize the barriers for continuous improvement taking into account the perspective of top managers, middle level managers and employees. Both the middle level managers and employees indicated the following as barriers for $\mathrm{CI}$ (continuous improvement) from the area of management: the lack of commitment and the lack of support from the top management. In turn, top managers did not indicate such shortcomings on their side. All three examined groups unanimously indicated barriers from the area of knowledge, namely the lack of sufficient knowledge on $\mathrm{CI}$ and the lack of knowledge sharing. 


\section{Lean leadership in the light of conducted research}

The research in two large and one medium production company was conducted in order to analyze and assess the implementation of lean leadership. Following the standard Toyota model related to shaping lean leadership as well as approaches represented in the literature on the subject and resulting from the experience of companies related to the implementation and maintenance of the lean approach (reports on implementations) as well as literature studies, a research tool in the form of a categorized interview was developed. The selection of the group of examined companies was intentional - the companies that have implemented and applied the concept of Lean Management and that have the lean leaders in their structures have been selected for interviews. The lean leaders have been asked about the implementation of the principles of lean leadership in the following areas of lean approach: culture of continuous improvement, selfdevelopment, qualifications, gemba, Hoshin Kanri.

All companies had a global scope of their operations. Two large companies are in the phase of maturity, the medium company is in the phase of growth and development. The first works related to the implementation of Lean Management began in the large companies 10 and 18 years ago - and 3 years ago in the medium-sized company. All lean leaders have been working in the examined companies for more than five years.

When asked whether the companies have defined and communicated the values followed by the company to all employees, only one company answered positively (the large company with the longest lean "period"). The remaining companies answered - "partially". All lean leaders currently experience (on the occupied post) the need to undertake new challenges and develop. All of them also believe that they currently have a possibility to satisfy these needs. When asked how a leader may develop at their current position, the following was indicated most often: new tasks, appearing challenges, trainings and cooperation with other leaders.

All examined lean leaders are open to accepting increasing responsibility so as to develop personally and develop others. All of them also believe that the previous personal development (in the present company) is satisfying for them. The leaders are trained, on average, once to three times a year. The main topics of training include: coaching, problem solving, conducting assessment interviews, development plans for the team, lean tools, motivating employees, time management, auditing processes, shop floor management.

All lean leaders currently using the knowledge and experience gained at their previous (lower) positions analyze the current situation and search for reasons 
for mistakes and translate the customer's needs to the objectives of individual processes and tasks for the employees. All of them also support their employees in the problem solving process. All of them also admitted to solving the problems for their employees at times. They do not give their employees the right to make mistakes and admit that the employees sometimes account for their mistakes (sanctions). Only a leader from a large company with a shorter lean period acts as a coach for the subordinate team.

All leaders make decisions based on facts confirmed in person in gemba. They do not use the time in gemba as an opportunity to teach (develop) their subordinates. Planning is poor as is the preparation of employees and processes in the long-term perspective.

Only leaders from large companies notice the need to make their employees independent (educate their successors).

All lean leaders recognize the needs of their subordinate employees regarding their development. Only a lean leader from a medium company does not have enough time to recognize these needs, the others have such time. Leaders from large companies responded that the employees' development is included in the company's strategy and that all employees have individual paths of development. Leaders undertake the following actions supporting the employees' development: external trainings (large companies), instructions at the work post (medium company), benchmarking meetings (all), problem solving process (all), coaching (one large company with a shorter lean period). When asked what the obstacle in developing their subordinate employees is, the answers were as follows: a limited budget (large company with a shorter lean period and a medium company), the lack of time for coaching (large company with a longer lean period) and the lack of time for training (medium company).

No leader indicated such obstacles as the employees' reluctance towards personal development. Lean leaders from two large companies confirmed that the company had created an environment in which objectives bringing improvement are coordinated at each level of the organization and employees in the entire organization share ideas for achieving them. There still is no such environment in the medium company. All lean leaders believe that challenges formulated by the environment are used to strengthen leadership in the organization. There is a sensei (master, teacher) in each company that provides lean leaders with coaching during the implementation and the maintenance of lean. Only a large company with a long lean period does not use external consultants regarding the development of leadership in the organization - others use such services. 
To sum up, we may say that the level of implementation of lean leadership in the examined companies (taking into account the perspective of the examined lean leaders) is satisfactory, although the fact of insufficient definition and communication of the values followed by the company to all employees is alarming. Only the company with the longest lean period approached this Iss. in a reliable manner. The biggest amount of work needs to be done related to shaping and implementing lean leadership in the medium company still at the beginning of the lean way.

To sum up, we may say that:

1. The level of implementation of lean leadership in the examined companies (taking into account the perspective of the examined lean leaders) is satisfactory, although the fact of insufficient definition and communication of the values followed by the company to all employees is alarming. Only the company with the longest lean period approached this Iss. in a reliable manner. The biggest amount of work needs to be done related to shaping and implementing lean leadership in the medium company still at the beginning of the lean way.

2. The attention in large companies was drawn to cooperation with other leaders in terms of the possibility of development at their current positions. This is an opportunity and an appropriate basis for the development of institutional leadership.

3. The level of implementation of the principles of lean leadership in the field of the culture of continuous improvement, self-development and qualifications is the most advanced in the examined companies.

4. The level of the implementation of these principles in the field of gemba and Hoshin Kanri (especially in the medium company) is a bit poorer.

5. A problem frequently noticed by lean leaders was the limited time for the implementation of actions related to lean leadership.

6. The fact that employees express their desire to cooperate and develop personally is exemplary. This is the achievement of lean leaders to a very large extent.

\section{Conclusion}

There is no ready formula to develop Toyota style lean leadership. However, one may gain inspiration from its experience. In order to maintain lean thinking in a company and the permanent continuous improvement system, the implementation of the leadership approach proposed by Toyota or a similar one 
is very important. This is confirmed by Toyota's long-term successes achieved even in the most adverse times of drastic changes. Toyota's approach towards leadership and the education of leaders does not ensure any quick changes and solutions. Shaping leaders at Toyota is a laborious and long-term process (Liker, Convis 2012, p. 68).

The literature studies and research confirm the significance of and the need to implement lean leadership. However, the level of implementation of lean leadership in many companies is still far from the model of leadership indicated by Toyota. Of course, the specific nature of the company as well as its needs and opportunities with regard to the implementation of lean leadership is a strong condition. However, using half-measures in the form of "convenient" principles is a short-term action. A consistent, comprehensive approach to the implementation of lean leadership and the compliance with a wide range of lean leadership principles is required from the long-term perspective.

\section{Summary}

\section{Implementation of lean leadership}

The Toyota case proves that lean leadership is of critical importance for the successful implementation and permanent functioning of Lean Production System. There is no ready formula for developing Toyota style lean leadership. However, one may gain inspiration from its experience.

Practice shows that many implementations of Lean Management do not meet expectation in the long term. In the beginning enterprises are mainly focused on waste elimination and expect quick results. However, in the long run they do not always manage to create a Lean thinking and consequently the continuous improvement process. An important link between the reduction of waste and continuous improvement could be the lean leadership.

The aim of this article is to present the role and importance of lean leadership for the successful implementation of lean concepts and the analysis and evaluation of the implementation of lean leadership in the practice of companies.

Keywords: Lean leadership, Lean Management, Lean Production System, continuous improvement. 


\section{Streszczenie}

\section{Realizacja lean leadership}

Przypadek Toyoty dowodzi, że lean leadership ma kluczowe znaczenie dla skutecznej implementacji i trwałego funkcjonowania LPS (Lean Production System). Nie ma gotowego przepisu na rozwijanie szczupłego przywództwa w stylu Toyoty. Jednakże można czerpać inspirację z jej doświadczeń.

Praktyka pokazuje, że wiele wdrożeń koncepcji Lean Management $\mathrm{w}$ dłuższej perspektywie nie spełnia pokładanych $\mathrm{w}$ nich nadziei. Przedsiębiorstwa na początku koncentrują się głównie na eliminacji marnotrawstwa i oczekują szybkich efektów. Jednakże w dłuższej perspektywie nie zawsze udaje się im stworzyć Lean thinking a $\mathrm{w}$ konsekwencji continuous improvement process. Ważnym ogniwem pomiędzy redukcją marnotrawstwa a ciągłym doskonaleniem powinno być przywództwo.

Celem artykułu jest przedstawienie roli i znaczenia lean leadership dla skutecznego wdrożenia koncepcji lean oraz analiza i ocena realizacji lean leadership $\mathrm{w}$ praktyce przedsiębiorstw.

\section{Słowa}

kluczowe: przywództwo w Lean, szczupte zarzadzanie, system szczuptej produkcji, ciagłe doskonalenie

\section{References}

1. Ciarniene R., Vienazindiene M. (2015), An Empirical Study of Lean Concept manifestation, Procedia - Social and Behavioral Sciences 207.

2. Dombrowski U., Mielke T. (2013), Lean Leadership - fundamental principle and their application, Procedia CIRP 7.

3. Dombrowski U., Mielke T. (2014), Lean Leadership - 15 Rules for a sustainable Lean Implementation, Procedia CIRP 17.

4. Emiliani M.L. (1998), Lean behaviors, "Management Decision”, Vol. 36 Iss. 9.

5. Friedemann L. (2014), Tapping the reservoir of continuous improvement potential: your employees, "Lean Management Journal", Vol. 8 Iss. 4.

6. Holtskog H., Martinsen K., Skogsrod T., Ringen G. (2016), The pivoting problem of Lean, Procedia CIRP 41.

7. Lam M., O'Donnell, Robertson D. (2015), Achieving employee commitment for continuous improvement initiatives, "International Journal of Operations \& Production Management", No. 2.

8. Liker J.K. (2005), Droga Toyoty, MT Biznes, Warszawa. 
9. Liker J.K., Convis G. L. (2012), Droga Toyoty doLean Leadership, MT Biznes, Warszawa.

10. Liker J.K., Franz (2013), Droga Toyoty do ciagłego doskonalenia, MT Biznes, Warszawa.

11. Miller J., Wroblewski M., Villafuerte J. (2014), Kultura Kaizen. Budowanie i utrzymanie kultury ciagłego doskonalenia, Warszawa.

12. Nogalski B. (2010), Lean Management, [in:] Czerska M., Szpitter A. (ed.), Koncepcje zarządzania, $\mathrm{CH}$ Beck, Warszawa.

13. Orr C. (2005), Lean Leadership in Construction, "Management of People and Teams", Proceedings IGLC-13, No. 7.

14. Walentynowicz P. (2013), Uwarunkowania skuteczności wdrażania Lean Management w przedsiębiorstwach produkcyjnych w Polsce, Wydawnictwo Uniwersytetu Gdańskiego, Gdańsk. 